\title{
Clinical epidemiology, not seroepidemiology, is the answer to Africa's AIDS problem
}

\author{
F I D KONOTEY-AHULU
}

If there is one thing veteran physicians, surgeons, public health experts, and other health workers in Africa have been good at it is clinical epidemiology. The work of Dr Cicely Williams (on kwashiorkor in west Africa) ${ }^{12}$ and Dr Denis Burkitt (on lymphoma in east Africa $)^{34}$ is a prime example of what careful clinical and epidemiological observation can produce. Some others who lived and worked in Africa and emphasised this kind of approach in tropical medicine and health include Shaper, Gelfand, Edington, Sai, Hutt, Lambo, Lucas, Morley, Gilles, Hendrickse, Koinage, Osuntokun, and Bryceson, to mention but a sample.

Now, suddenly, with the acquired immune deficiency syndrome (AIDS), something called seroepidemiology is being pushed-by people who have no knowledge of tropical medicine-way above clinical epidemiology rather than being made to work shoulder to shoulder with it. While travelling extensively in sub-Saharan Africa recently I encountered great disquiet about this approach. For example, Dr Miriam Duggan, the obstetrician-gynaecologist medical superintendent of the large St Francis Hospital Nsabya, in Kampala, was saddened by the way that external research agencies lost interest whenever she mentioned the need for strengthening her clinical epidemiological research base to enable her go round the villages to follow up and treat patients with AIDS who had been discharged, and to measure longevity. Research funds must never be for service ("that is the sole burden of the Ugandan government"), she seems to have been told, but are for taking the blood of as many people as possible to measure "seropositivity" and T lymphocytes.

These measurements are indeed important to indicate what is happening in the population, but there must not be an "either research or service" approach to health problems in the Third World. The greatest contributions to medical knowledge in Africa by individuals (Cicely Williams, Denis Burkitt, etc) or by agencies

Cromwell Hospital, London SW5 0TU

F I D KONOTEY-AHULU, MD, FRCP, consultant physician (the World Health Organisation, International Atomic Energy Agency, etc) have been made when research was coupled with service. For one thing, there is far more cooperation from the people when problems are seen to be tackled. I had far more cooperation from the prostitutes I met when I discussed their problems and fears about AIDS (and in some cases future rehabilitation) than I would have got by just distributing a questionnaire (unpublished findings).

\section{Unreliability of seroepidemiology}

If seroepidemiology had been consistently reliable in defining correctly the seriousness of Africa's AIDS problem there would have been less disquiet about it in the countries I visited. But Biggar et al described very high rates of seropositivity in Kenya and eastern Zaire, ${ }^{6}$ only to remark a year later, "We now believe that the reactivity reported was not specific" for human $T$ cell lymphotropic virus type III (HTLV III) ${ }^{7}$ - a conclusion already arrived at by the more extensive investigations of a team of German and British workers. ${ }^{89}$ Indeed, using more than 6000 samples from African subjects, Wendler et al showed "that fewer than one in a 1000 were seropositive for AIDS at the time of sampling before 1985 and (the data) do not support the hypothesis of the disease originating in Africa." This information came too late to prevent extravagant projections of the AIDS problem in Africa ${ }^{10}$ and to restore the confidence of Africans in seroepidemiology.

Investigators with a knowledge of tropical medicine quite rightly observed that "associated with recurrent malaria and other infectious diseases, excessively high rates of false-positivity with H9/HTV-III ELISA have led to a dichotomy between seroepidemiology and clinical epidemiology in tropical Africa." In addition, "patients with alcoholic liver disease have a high incidence of false positive results on tests for HTLV-III antibodies,"12 while acute malaria infections have produced false positivity even with the Western blot. ${ }^{13}$ When the conclusions of clinical epidemiology differ from those of seroepidemiology clinicians should always believe the former. Clinicians with considerable experience of 
Africa told Biggar that if AIDS had existed there while they were practising they would have recognised it, but he seemed to dismiss their conviction and described "this type of evidence" as anecdotal. ${ }^{14} \mathrm{He}$ came to agree with them only after "reviews of the records of the Belgian and French hospitals" at which Africans were treated, concluding that AIDS became common only after $1980 .^{1+}$

During my travels through sub-Saharan Africa I was heartened to observe that there are enough trained health workers in post who can work out the clinical epidemiology of AIDS à la Cicely Williams and Burkitt with a minimum of fuss. Granted, seroepidemiology seems to be the more "scientific," but really it achieves less and uses more resources. When Jonathan Mann wrote recently that "It is difficult to gauge the spread and seriousness of AIDS in Africa; African countries lack diagnostic equipment and testing facilities"15 he must have been referring to seroepidemiology. Primary health care in Ghana, for instance, is so good that there is no difficulty in tracing patients with AIDS and their relatives, and a field unit in south western Uganda does not have to rely on seroepidemiology to gauge the spread and seriousness of AIDS in Africa. I cannot, of course, speak for Zaire, which was the only country that turned down my application for a visa so that I could visit medical colleagues and discuss health problems.

\section{How to spend the money available}

If funds were limited, as indeed they are in much of Africa, I would limit serological work to (1) assessing the specificity and sensitivity of the various kits under African conditions (as researchers like Rosemary Mwendapole are doing at Ndola in Zambia); (2) screening all blood before transfusion starting from the cities (as Kenya has begun to do); and (3) serving as a back up procedure when clinical features are not clear cut (as I saw being done in Dar es Salaam and Lusaka). I would assume that prostitutes at ports and on trade routes, and the promiscuous, were seropositive even if they were not and direct educational programmes accordingly. I would not embark on an expensive wholesale screening for AIDS. In my tribe, starting with those who have got AIDS, I would spend the bulk of any available funds on answering the questions: How, when, who, which, why, and where?

The usual objection to this approach is that "those who are sick with AIDS have no more people to infect so it is better to identify the carriers and thereby stop the spread of the disease." The answer to this is that I was unable to find a team in any of the countries I visited whose policy was to inform all those with "positive serum" that they had AIDS to make them behave appropriately. It was far easier to advise everybody to behave appropriately rather than base caution on seropositivity. For example, in Congo Brazzaville, a predominantly Roman Catholic community though Marxist in its governmental politics, I asked what advice the doctors gave to a married man with tuberculosis who was found to be seropositive and they said: "Nothing." The patient was not even told that he might have AIDS because the doctors, quite rightly, said that they had nothing else to go on but seropositivity for human immunodeficiency virus as assessed by ELISA and pulmonary tuberculosis. If it had been proved with virus isolation studies, etc, that the man had AIDS would the doctor tell him to protect his wife? The doctor pondered a little and then said that there was little point in telling him about it: the recommendation to use condoms was religiously unacceptable, and in any case "the man has improved on antituberculosis therapy and the wife is still seronegative." This raises the question: Does seropositivity in a patient with tuberculosis (or amoebiasis or strongyloides, for that matter) always mean AIDS? Only clinical epidemiology can answer that question in Africa, and this is why it is to be preferred.

\section{Data that need to be ascertained}

Clinical epidemiological questions I should like health workers, patients, and their relatives to tackle in my Krobo tribe in south eastern Ghana, where there is only repatriation of people with AIDS are the following:

(1) Why of two girls who leave home on the same day for prostitution in Abidjan does one return sick with AIDS and the other not?

(2) What type of "abnormal sex" did the one girl have and the other not?

(3) Which clients were frequented by the one and not the other?

(4) How was the prostitution organised: were the girls self employed and regulated or did someone "own" them and pay them wages?

(5) Where did they carry on business: in brothels, in hotels, on board ships, or in the homes of clients?

(6) When exactly did the girl with AIDS fall sick?

(7) Who treated the girls when they were ill (quacks?) and how were they treated? And with dirty needles?

(8) What physical signs does the patient have in the perineum and elsewhere?

(9) Have any of the returned patients (repatriated with AIDS from Abidjan and Hamburg) improved after treatment with traditional herbal medicine?

(10) How long do the patients live?

(11) When will the first Krobo man develop the disease, and under what circumstances?

(12) Why do prostitutes return home with AIDS from the Ivory Coast and not from Nigeria?

With little more funds than are required to treat these patients a lot of data can be collected. In other tribes in Africa where AIDS has proceeded from the introduction phase to the propagation phase and men have developed the disease data need to be collected on circumcision state (for men and women); abnormal sex practices; longevity of men, women, and infants; the phenomenon of the healthy infected mother (the "perpetual virus secreting mother," who continues to conceive and to bear babies with AIDS); and the most effective education slogans and posters, which will vary from tribe to tribe. With pure clinical epidemiology (and without waiting for a vaccine) a lot can be achieved in halting the march of AIDS in Africa, especially if other public health measures for the community are incorporated in the procedures. As I pointed out previously in respect of another disease in the Third World, "SERVICE, Education, research-in that order of priority-will guarantee patients' co-operation, but reversing the order, as often happens, to RESEARCH, Education, service succeeds in driving some away."

I thank the ministers of health, directors of medical services, and other health workers who readily agreed to discuss AIDS with me in the context of Africa's other problems.

\section{References}

1 Williams CD. A nutritional discase of childhood associated with a maize diet. Arch Dis Child $1933 ; 8: 423-8$.

2 Williams $C D$. Kwashiorkor-a nutritional disease of children associated with a maize diet. Lancel 1935;ii:1151-2.

3 Burkitt D. A sarcoma involving the jaws in Atrican children. Brf Surg 1958;46:218-9.

4 Burkitt D, Wright D. Gevgraphical and tribal distribution of the African lymphoma in Uganda. BrMed J 1966; ; :569-72.

Biggar RJ, Johnson BK, Oster C, et al. Regional variation in prevalence of antibody against human T-lymphotropic virus types I and III in Kenya, east Africa. Int 1 Cancer 1985;35:763-7.

Biggar RJ, Melbye M, Kestens L, et al. The servepidemiology of HTLV-III antibodies in a remote population of eastern Zaire. Br Med $\mathcal{J}$ 1985;290:808-10.
pisar

population of eastern Zaire. Br Med J 1985;290:808-10.
Biggar RJ, Saxinger C, Sarin P, Blattner WA. Non-specificity of HTLV-III reactivity in sera from Biggar RJ, Saxinger C, Sarin P, Blattner WA. Non-specificity of
rural Kenya and eastern Zaire. East Afr Med J 1986;63:683-4.

8 Hural Kenya and eastern Zaire. East Afr Med J 1986;63:683-4. Hunsmann G, Sch
1985;ii:952-3.

9 Wendler I, Schneider J, Gras B, Fleming AF, Hunsmann G, Schmitz H. Seroepidemiology of human immunodeficiency virus in Africa. Br Med $\mathcal{J}$ 19\%6;293:782-5.

10 Panos Institute. AIDS and the third wurld. London: Panos Institute, 1986.

11 Fleming AF, Kazi AR, Schneider J, et al. Comparison of H9/HTLV-III and ENV-80 ELISAs as screening in tropical Africa: prevalence of anti-LAV/HTLV-III in some Zambian patients. AIDS-Forschung (AIFO) 1986;8:434-40.

12 Mendenhall CL, Roselle GA Grossman CJ, Rouster SD, Wesner RE. False positive tests for HTLV-III antibodies in akcoholic patients with hepatitis. N Engl J Med 1926;314:921-2.

13 Volsky DJ, Wu YT, Stevenson M, et al. Antibodies to HTLV-HILLAV in Venezuelan patients with acute malarial infections. N Engl J Med 1986;314:647-8.

4 Biggar RJ. The AIDS problem in Africa. Lancet 1986; : 79-83.

14 Biggar RJ. The AIDS problem in Africa. Lancet 1986;

16 Konotey-Ahulu FID. Survey of sickle-cell disease in England and Wales. BrMed $\mathcal{f}$ 1982;284:112.

(Accepted 27 May 1987) 